\title{
A 21/2D-s marás algoritmusa SFCAM környezetben történő CNC programozáshoz
}

\author{
Magyar Attila
}

A dolgozat bemutatja a számitógéppel segitett müszaki tervezésnek (CAM) a számitógéppel integrált gyártástechnológiában betöltött szerepét. Betekintést ad az algoritmusba, mint a számítógépes felhasználás alapvető eszközébe. Felhasználói segítséget nyújt a napjainkban elterjedt tervezőrendszer, az SFCAM (Shop Floor CAM) programozási feladatainak ellátására. Igyekszik elősegiteni a $2 \frac{1}{2} \mathrm{D}-\mathrm{s}$ marás SFCAM környezetben történő programozásának alapszintü megismerését. A kecskeméti Gépipari és Automatizálási Müszaki Főiskola NC-technológia szakirány tananyagában szerepel az SFCAM szoftver megismerése, melynek felhasználása során merült fel a $2 \frac{1}{2} \mathrm{D}-\mathrm{s}$ marás $\mathrm{CNC}$ programozásához szükséges technológiai tervezésnek, valamint az SFCAM szoftver 21/2D-s maró modul technológiai tervezésének az algoritmizálása. A hagyományos, és az SFCAM szoftverrel történő technológiai tervezés összehasonlitása az utolsó fejezetben történik, egyszerübb példákkal szemléltetve.

\section{A gyártás automatizálásának mai eszközrendszere}

A gyártás automatizálásának mai eszközrendszerét az úgynevezett CIM - Computer Integrated Manufacturing (számítógéppel integrált gyártás) rendszereken keresztül célszerü tanulmányozni, mivel az anyag- és adatfeldolgozás automatizálásának egységét ma ezek a rendszerek valósítják meg a legmagasabb szinten. A CIM intelligens elektronikát alkalmazó gyártási rendszer, amely gyártóberendezések, informatikai rendszer és irányítási rendszer együttese. E rendszerek számítógéppel integrálják a gyártás mindazon funkcióit, a számítógépes gyártmány- és gyártástervezést, a termelésirányítást, a gyártást (beleértve a minőségellenőrzést, a szerelést és felületkezelést), a kiszolgálást, anyag- és termelőeszköz-szállítást, a készletezést és raktározást, amelyeket eddig külön alrendszerek kezeltek.

A gyártási folyamatirányítás ( CAM ) a CIM rendszer egyik legösszetettebb informatikai alrendszere. CAM - Computer Aided Manufacturing: számítógéppel segített gyártás, közvetlen gyártásirányítást és felügyeletet ellátó funkció, amely szabályozza egy-egy gyártóberendezés müködését. CIM intelligens elektronikát alkalmazó gyártási rendszer, amely gyártóberendezések, informatikai rendszer és irányitási rendszer együttese. E rendszerek számítógéppel integrálják a gyártás mindazon funkcióit, a számítógépes gyártmány- és gyártástervezést, a termelésirányítást, a gyártást (beleértve a minőségellenőrzést, a szerelést és felületkezelést) a kiszolgálást, anyag- és termelöeszköz-szállitást, a készletezést és raktározást, amelyeket eddig külön alrendszerek kezeltek. A CAM tevékenység a gyártástervezéssel indul. Ez magába foglalja a technologizálást, szerszámozást, stb.

\section{A 21/2D -s marás}

A 2 $\frac{1}{2}$ D-s marási mód azt jelenti, hogy a megmunkálás során a szerszámot két tengely mentén csak valamely síkban tudjuk mozgatni, a harmadik tengelyt pedig gyorsmenetre, vagy a munkadarab megközelítésére, illetve fogásvételre használhatjuk. A CNC marók síkban való mozgást igénylő alakzatok megmunkálására, két tengely menti interpoláció által nagybonyolultságú alakzatok kialakítására is alkalmasak, azonban térbeli alakzatok (3D) készítésére nem minden gép képes, mert ehhez már bonyolult matematikai összefüggések szükségesek. A $2 \frac{1}{2} \mathrm{D}$ egy áthidaló megoldás, amelynél egy térbeli alakzatot két koordináta 
egyidejủ használatával lehet kialakítani. Ez úgy történik, hogy a munkadarabot síkokra osztjuk, és ezen síkok mentén végezzük a megmunkálást. Ilyenkor a harmadik koordináta a ráállást végzi, igy a síkbeli megmunkálás a harmadik tengely kiegészítő mozgása révén térbeli megmunkálássá alakul át. A megmunkálás pontossága a kiegészítő mozgást végző tengely lépésközeinek nagyságától fủgg. Minél több síkra osztjuk fel a munkadarabot, és ezek minél közelebb kerülnek egymáshoz, annál nagyobb pontosságot és jobb felületi minőséget érhetünk el.

A gyártási folyamat kezdetét legjobban az indító információhalmaz megjelenítésével, befejezését a kész munkadarabban tárolt információhalmazzal tudjuk jellemezni. A marási mód megválasztásakor figyelembe kell venni a leválasztandó anyag mennyiségét, a munkadarab alakját és méreteit, valamint a megmunkálandó felület alakját (sík, horony, alakos felület stb.). A technológia megtervezésekor a bemenő adat: a gyártandó sorozat nagysága, a munkadarab és szerszám anyaga, tulajdonságai, a gyártási költségek, stb. A kimenö adat: a választott gép, szerszámok + paraméterek + technológia.

\section{Az információleképzés elemei}

A geometriai információ-feldolgozás és leképzés fö elemei a gyártási folyamatban:

1. gyártástervezés, gyártáselőkészítés például: művelettervezés, keszüléktervezés, stb.,

2. gyártóeszközök előkészitése például: szerszámgépek, szerszámok, készülékek kiválasztása,

3. munkadarabgyártási folyamatok, melyek eleme a relatív mozgás a munkadarab és a szerszám között.

A munkadarabra leképzett információkat a leképzés eszközein keresztül három részre lehet bontani : $\mathrm{A}=$ szerszámgépek (alapinformációtárolók); $\mathrm{B}=$ szerszámok; $\mathrm{C}=\mathrm{a}$ gép irányításából származó információhalmaz; MI = a munkadarabra leképzett információk.

Így tehát,

$$
\mathbf{M I}=\mathbf{A} \cup \mathbf{B} \cup \mathbf{C}
$$

\section{Az algoritmusok}

A számitógépes felhasználás alapvető eszköze a számitógépes program, amely algoritmus alapján készül el. A programozás informatikai értelemben azt jelenti, hogy egy feladat megoldási módszerét úgy formálják, hogy azt egy számítógép végre tudja hajtani. A programozónak ehhez különféle megoldási módszereket (algoritmusokat) és adatstruktúrákat kell ismernie, amelyekkel a megoldást a legkedvezőbben lehet leírni. Az algoritmus, egy feladat számítógépen történő megoldására szolgáló eljárás. A feladat megoldásának lépésekre bontását algoritmizálásnak nevezzük. A gyártástechnológia tervezési folyamataiban is előfordulnak algoritmizálandó feladatok. Jelen esetben kétféle technológiai tervezés algoritmizálását kell vizsgálni.

\section{Az algoritmusok legfontosabb tulajdonságai}

1.Végesség. Az algoritmus véges sok lépés után befejezödik. 2.Meghatározottság. Az algoritmus minden lépésének pontosan meghatározottnak kell lennie. A végrehajtandó utasításnak minden esetben világosnak és félreérthetetlennek kell lennie. 3.Bemenet. Az algoritmus olyan adatokat igényel, vagy nem, amelyeket az elindítása előtt meg kell adni. Ez az adat mindig meghatározott halmazokból kerülhet ki. 4.Kimenet. Az algoritmushoz egy vagy több kimenet tartozhat, amelyek meghatározott kapcsolatban állnak a bemenettel. 5.Elvégezhetôség. Az algoritmust végre lehessen hajtani. Az algorimus során végrehajtandó utasításoknak egyszerünek kell lennie ahhoz, hogy az ember véges idő alatt pontosan végrehajthassa.

$\mathrm{Az}$ algoritmusokban a lépések elrendezése néhány mintát követ. Ezek: müveletsorozat, elágazás, hurok (ciklus). Többféle szempont szerint lehet osztályozni az algoritmusokat, például: struktúra jellemző, vagy feladatok tárgyköre szerint. Ezek a felosztások nem teszik teljes mértékben lehetővé valamennyi algoritmus besorolását, de segítenek a tájékozódásban. A $2 \frac{1}{2} \mathrm{D}-\mathrm{s}$ marás technológiai tervezéséhez szükséges algoritmusokat a számítási folyamatábra segítségével célszerü elkészíteni. 


\section{A 21/2D-s marás technológiai tervezésének algoritmusai}

A CNC programozáshoz, a technológiai tervezés föbb részeinek megfelelően ötféle algoritmust kell elkésziteni. Ez a szerszámgép, a készülék, a szerszám, a technológiai paraméterek és a szerszámpálya kiválasztásának algoritmusa. Mindegyik algoritmusnál a bemeneti információkat a munkadarab jellemzői adják, úgymint: a munkadarab mérete, geometriája, darabszáma, felületi minösége, stb. A következö lépésekben feltételek segítségével lehet meghatározni a kimeneti információt, ami a kiválasztásra kerülö technológiai jellemző. Az l.ábrán például a szerszámgép kiválasztásának algoritmusa látható.

\section{A 21/2D-s marás technológiai tervezésének algoritmusai SFCAM környezetben}

Az algoritmusok segítségével végig tudjuk követni, hogy a tervezés során, a programban milyen müveleteket kell végrehajtani. Az algoritmusok között található egy fő ág, amely további mellékágakra oszlik. A fö ág tartalmazza a programozáshoz szükséges alapvető programozási múveleteket, valamint a program felépítését. A mellékágak részletes útmutatót adnak a müveletekről, például: programelinditás, szerszámkiválasztás, megmunkálási technológiák kiválasztása, stb. A mellékágakat bonyolultságuktól függően további ágakra lehet bontani. Az egyes algoritmusokban, a részalgoritmusokra való hivatkozás körök segítségével történik, ezekben található számok utalnak az elérendő algoritmusok hollétére. A 2.ábrán például a maró modul és a posztprocesszor kiválasztása algorimus látható.
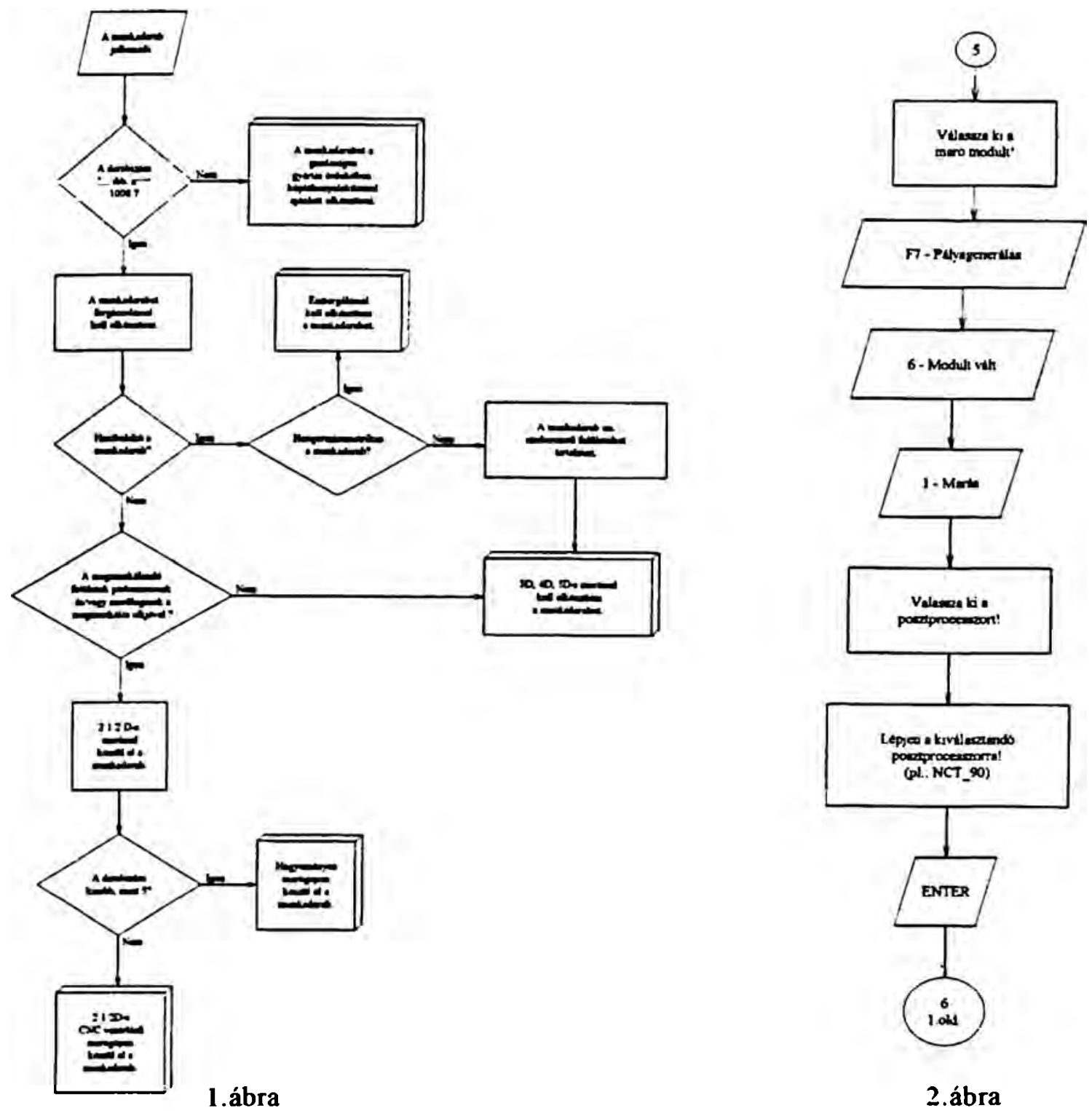


\section{Az Shop Floor CAM rendszer}

Az SFCAM olyan gyártási tervezö rendszer, amely az $\mathrm{NC} / \mathrm{CNC}$ gépek programozási feladatainak ellátására alkalmas. CNC alkatrészprogramok készithetők marógép, esztergagép és szikraforgácsoló gépek számára. A szoftverrel létrehozhatunk egy geometriai adatbázist, és a rendelkezésre álló technológiák valamelyikét összerendelhetjük egy CNC program formájában, igy az általunk kiválasztott $\mathrm{NC} / \mathrm{CNC}$ gépre megszerkeszti a programot.

\section{Az SFCAM üzemmódjai}

A szoftver alapvetően három üzemmóddal rendelkezik: geometriai mód, szerkeszıó mód, könyviár mód. Az SFCAM a következő modulokat kezeli: maró modul, eszlergáló modul, szikraforgácsoló modul, lemezmegmunkáló modul / nibbelö, lángvágó és laservágó /.

Ha a geometriai alakzat a számítógép memóriájában van, egyszerủen válasszuk ki a szerszámunkat a szerszám könyvtárunkból, nevezzük meg a müveletet, és az SFCAM felkínálja a megfe lelö opciókat a megmunkálás teljesítésére. A szerszámpálya vagy azonnal megjelenik a grafikus képernyön, vagy vonalasan a szerszámközéppont mozgását ábrázolva, vagy a szerszám alakjának megjelenítésével a megmunkálás animációjaként.

Az általános szerszámpálya müveletek a következök:

- kezdési, szerszámcsere, befejezési eljárások, szubrutinok,

- paraméter-beállítás,

- az utolsó blokk vagy szekció ismétlèse, eltolása, forgatása,

- posztprocesszor hívás,

- modul és posztpro-cesszor kiválasztás.

A $21 / 2 \mathrm{D}$-s maró modul jellemzö müveletei a következök:

Fúrási ciklusok minden típusa. Horonymarás (egyenesek vagy formák mentén), gravírozás.Kontúrozás kiválasztott ráfutás és elhagyás módokkal. Nagyolóciklusok. Zseb- , és sziget-kialakitás. Idommarási ciklusok (kör, doboz, ívszelvények).

\section{A programozás lépései}

Az SFCAM programmal végzett munka négy fö lépésböl áll:

1. A geometriának, vagy egy részének a felépítése. Nem szükséges a teljes geometria megszer kesztése a megmunkáló parancsok összetettségének köszönhetöen.

2. A nyersanyag kiinduló méreteinek, és az általános megmunkálási paraméterek meghatározása.

3. A szerszámok kiválasztása, a megmunkáló ciklusok meghívása az egyes szerszámok számára.

4. Az alkatrészprogram lezárása a befejezés paranccsal. A posztprocesszor elindítása a kiválasz tott vezérléshez történő programgeneráláshoz. Az így elöállított program közvetlenül átjuttat ható $\mathrm{CNC}$ vezérlönkre.

\section{Irodalom}

[1] Dr. Tóth Tibor: Automatizált müszaki tervezés a gépgyártástechnológiában. Tankönyvkiadó, Budapest, 1990.

[2] Dr. Tajnafői József: Szerszámgéptervezés I. Nemzeti Tankönyvkiadó, 1993.

[3] Prof. Dr.-Ing. Horst Czichos: HÜTTE. A mérnöki tudományok kézikönyve. Springer Hungarica Kiadó Kft. , Budapest, 1993.

[4] Shop Floor CAM. Referencia kézikönyv. 